\title{
KAJIAN LITERATUR PERKEMBANGAN \\ PENGETAHUAN FONETIK \\ PADA ANAK USIA DINI
}

Oleh:

Martha Christianti, M.Pd

PAUD FIP Universitas Negeri Yogyakarta

Email: marthachristianti@uny.ac.id

\begin{abstract}
Abstrak
Artikel ini merupakan kajian literatur perkembangan pengetahuan fonetik pada anak. Fonetik berkaitan dengan bunyi bahasa dan simbol. Perkembangan fonetik pada anak terjadi sangat alami pada kemampuan bahasa reseptif dan produksi bahasa. Tahap perkembangan pengetahuan fonetikpada anak terbagi dalam tahap bayi, batita, prasekolah dan taman kanakkanak. Setiap tahap perkembangannya menunjukkan karakteristik yang khusus. Pengetahuan tentang perkembangan pengetahuan fonetik berguna bagi guru dalam menstimulasi fonetik anak dan bagi peneliti untuk melakukan penelitian terhadap fonetik anak dalam konteks budaya Indonesia.
\end{abstract}

Kata kunci: perkembangan pengetahuan fonetik

\begin{abstract}
This article is a review of the literature about the form of phonetic knowledge development in children. Phonetics associated with the sounds of language and symbols. This expansion is happening very naturally of receptive and production abilities of language in children. Phase development of phonetic knowledge on child is divided into stages infant, toddler, preschool, and a kindergarten. Each stage shows specific developments of characteristic phonetic knowledge.Educators must know about this development of phonetic knowledge to provide stimulation, and for researcher as a research study on children phonetic in the context of Indonesian culture.
\end{abstract}

Keywords: Development of phonetic knowledge

\section{PENDAHULUAN}

Seorang bayi menoleh kearah sumber suara ketika namanya dipanggil. Bunyi ocehan bayi yang mengikuti intonasi orang dewasa. Anak menyukai permainan menggunakan kata-kata yang terdengar berbunyi sama namun memiliki makna yang berbeda. Anak menyukai lagu-lagu dan sajak yang memiliki rima sama. Semua contoh yang dipaparkan di atas merupakan bentuk dari pengetahuan fonetik yang berkembang dalam diri anak. Pengetahuan fonetik merupakan salah satu aspek pengetahuan yang terdapat dalam perkembangan bahasa, selain aspek pengetahuan bahasa yang lain yaitu pengetahuan semantik, sintaksis, morfemik, dan pragmatik. Pengetahuan fonetik adalah pengetahuan mengenai hubungan bahasa-simbol di dalam bahasa (Erika Hoff, 2009). Pengetahuan fonetik pada anak dibantu oleh kemampuan anak memahami perbedaan bunyi dan cara menggunakan bahasa di sekitar anak.

Beberapa istilah dalam perkembangan fonetik yaitu fonem, fonetik, fonemik, dan fonologi. Hasil telaah di id.wikipedia.org, fonologi adalah ilmu tentang perbendaharaan bunyi-bunyi (fonem) bahasa dan distribusinya. Asal kata fonologi terdiri dari gabungan kata fon (artinya bunyi) dan logi (yang berarti ilmu). Istilah lain yang berkaitan dengan fonologi antara lain fona, fonem, vokal, 
dan konsonan. Fona adalah bunyi ujaran yang bersifat netral atau masih belum terbukti membedakan arti, misalnya $\mathrm{k}$ pada pasangan kata tuti dan tutik, atau o pada pasangan kata besok dan besuk, atau $\mathrm{h}$ pada pasangan kata bila dan bilah (Muliani Rahmah, 2011). Fonem adalah satuan bunyi ujaran terkecil yang membedakan arti, misalnya, $r$ dan $\mathrm{s}$ pada kata buruk dan busuk, atau $t$ dan $r$ pada kata peti dan peri (Muliani Rahmah, 2011).Gambar atau lambang fonem dinamakan huruf. Dalam bahasa Indonesia, fonem terdiri dari enam fonem vokal yaitu a, i, u, e, ə, dan o; delapan belas fonem konsonan yaitu $\mathrm{p}, \mathrm{t}, \mathrm{c}$, $\mathrm{k}, \mathrm{b}, \mathrm{d}, \mathrm{j}, \mathrm{g}, \mathrm{m}, \breve{\mathrm{n}}, \mathrm{y}, \mathrm{n}, \mathrm{s}, \mathrm{h}, \mathrm{r}, \mathrm{l}, \mathrm{w}$, dan y; dan penambahan empat fonem dari bahasa asing yaitu $\mathrm{x}, \mathrm{z}, \mathrm{f}, \int$; dan tiga fonem diftong yaitu ai, au, dan oi.Variasi fonem karena pengaruh lingkungan yang dimasuki atau perbedaan realisasi pelafazan fonem karena posisi yang berbeda dalam kata disebut dengan alofon. Contoh alofon dalam bahasa Indonesia yaitu fonem /b/ dilafazkan ketika diawal kata "besar", dan ditengah kata "kabel" berbeda dengan diakhir kata "jawab"(id.wikipedia.org). Variasi fonem lain terdiri dari vokal, konsonan, diftong (vokal rangkap), dan kluster (konsonan rangkap). Muliani Rahmah (2011) menjabarkan masing-masing bunyi tersebut beserta contohnya. Bunyi vokal adalah bunyi ujaran yang keluar dari paruparu tanpa mendapat halangan, contohnya, a, i, u, e, o. Bunyi konsonan adalah bunyi yang keluar dari paru-paru mendapat halangan, contohnya, b, c, d, k, l, t, j, m, n, $\mathrm{q}$, dan $\mathrm{r}$. Bunyi diftong adalah bunyi dua vokal yang berurutan yang sekaligus digunakan sebagai sebuah suku kata, misalnya ai, au, dan oi. Menurut Internasional Phonetis Alfabet (IPA)(id.wikipedia.org; Achmad H.P, dan Alek Abdullah, 2012) contoh ai bunyinya /ay/ pada kata santai, cukai dan lambai, sedangkan au bunyinya /aw/ pada kata kerbau dan harimau, dan oi bunyinya /oy/ pada kata koboi dan amboi. Beberapa contoh kata dengan deretan vokal tidak disebut diftong yaitu buah, lauk, daur, semua, bau, lain, dan mencintai. Bunyi kluster adalah bunyi yang dihasilkan dari konsonan rangkap, contohnya kata film, drama, tradisi, dan modern (Sugianto, 2011).

Fonetik dan fonemik merupakan bagian dari fonologi. Fonetik adalah bagian fonologi yang mempelajari cara menghasilkan bunyi bahasa atau cara suatu bunyi bahasa diproduksi oleh alat ucap manusia dengan kata lain fonetik mempelajari cara kerja organ tubuh manusia terutama yang berhubungan dengan penggunaan dan pengucapan bahasa.Fonemik adalah bagian fonologi yang mempelajari bunyi ujaran menurut fungsinya sebagai pembeda arti dalam kata lain fonemik adalah kajian atau analisa bunyi bahasa dengan memperhatikan statusnya sebagai pembeda makna (id.wikipedia.org).Pengetahuan fonetik tidak berkembang sendiri dari aspek pengetahuan bahasa yang lain namun berkembang bersamaan dengan aspek pengetahuan semantik, sintaksis, morfemik, dan pragmatik.

\section{Perkembangan Pengetahuan Fonetik pada Bayi}

Bayi memperoleh bahasa dimulai dari mendengar bunyi ujaran dari orangorang disekitarnya. Bayi belajar mendengarkan bunyi ujaran yang terdengar hampir sama namun memiliki makna berbeda. Pengetahuan fonetik bayi dalam bahasa reseptif berkembang ketika mendengar bunyi ujaran di lingkungannya (Ulfa, 2011). Para peneliti melakukan penelitian tentang daya pemahaman bunyi fetus ketika periode akhir sebelum dilahirkan. Daya pemahaman bunyi pada fetus menunjukkan bahwa kemampuan untuk mendengar sudah mulai berkembang mulai kehamilan 25 minggu untuk menerima bunyi dan usia 35 minggu untuk ketajaman pendengaran seperti orang dewasa (Beverly Otto, 2015).Fakta ini dibuktikan dengan hasil penelitian tentang daya pemahaman bunyi pada fetus. 
Adapun cara mengukur daya pemahaman bunyi pada fetus adalah dengan mengamati ritme jantung fetus ketika mendengarkan bunyi ujaran. Dari hasil penelitian tersebut terlihat bahwa fetus yang didengarkan bunyi ujaran baru, detak jantungnya menurun. Namun ketika bunyi tersebut diulangi kembali, detak jantung fetus kembali normal. Ini menunjukkan bahwa untuk mendengar bunyi yang kedua dan seterusnya, fetus terbiasa dengan bunyi ujaran tersebut.

Hasil penelitian tentang kemampuan daya pemahaman bunyi pada masa bayimenunjukkan bahwa pada usia 4 hari, bayi lebih suka mendengarkan suara ibunya dibanding bahasa yang lain. Perilaku suka mendengarkan suara ibu (suara yang sering didengar) ini juga terlihat dari respon berbeda bayi pada bahasa lain yang tidak sering didengar ketika masih di dalam kandungan. Respon berbeda dibuktikan dengan botol susu yang dihisap oleh bayi. Bayi menghentikan hisapannya ketika mendengar bunyi ujaran baru yang diperdengarkan padanya. Ketika bunyi tersebut diulangi kembali secara terus menerus, bayi kemudian mulai menghisap botol susu seperti semula. Kemampuan tersebut menunjukkan bahwa di awal kelahirannya bayi dapat membedakan fonetik yang muncul dalam bahasa alami. Beverly Otto (2015) mengemukakan bahwa pada masa bayi awal, usia 1 bulan, bayi mampu membedakan fonem-fonem khusus dan mampu mengenali dan mengkategorikan fonem yang sama pada usia 5 bulan. Pada masa bayi akhir, usia 8 sampai 10 bulan, bayi lebih memperhatikan perbedaan bunyi-fonem yang ada dalam bahasa ibunya dan cenderung untuk tidak memperhatikan bunyi fonem dengan bahasa yang lain.

Secara ekspresif, pengetahuan bahasa fonetik anak berkembang dari bunyi ujaran yang didengar disekitar anak. Bayi dibatasi oleh aspek fisik yang belum matanguntuk memproduksi bunyi ujaran. Kematangan produksi bunyi ujaran melibatkan koordinasi sistem saluran suara yang terdiri dari pangkal tenggorokan, batang tenggorokan, langit-langit bagian depan dan belakang, rahang, bibir, dan lidah serta koordinasi pernafasan dengan pita suara. Misalnya, pangkal tenggorokan bayi masih tinggi dan dekat dengan rongga mulut, sehingga sistem saluran suara sangat kecil. Pada usia 4 bulan saluran suara bayi berubah dari bentuk miring menjadi melengkung. Posisi ini memudahkan anak untuk memproduksi suara karena bentuk lengkungnya seperti pada orang dewasa. Kematangan secara fisiologi tersebut akan semakin terkontrol ketika usia anak semakin bertambah. Selain itu, produksi bunyi ujaran dipengaruhi pula oleh perkembangan dan kematangan sistem saraf di otak. Misalnya, bayi yang mengoceh terjadi ketika selubung mielin pada akson yang ada di sel otak mampu mengontrol kegiatan motorik. Selubung protein berkembang bersama dengan akson yang memisahkannya dan menjadi impuls saraf untuk berjalan sepanjang akson dari kemungkinan terjadinya sirkuit pendek pada neutron lain yang ada didekatnya selama proses mielinasi (Beverly Otto, 2015).

Produksi bahasa menurut Beverly Otto (2015) berkaitan dengan pengetahuan fonetik diawal kehidupan anak dimulai dengan vokalisasi awal. Vokalisasi awal bayi pada mulanya reflektif, kemudian menjadi nonreflektif. Vokalisasi reflektif berasal dari keadaan fisik bayi seperti menangis, batuk, dan cegukan. Vokalisasi nonreflektif seperti mendekut dan mengoceh. Bunyi mendekut adalah bunyi vokal yang panjang seperti ooooo, eeee, aaaa, eeeh. Tahap mendekut merupakan tahapan penting untuk perkembangan fonetik anak karena pada tahap ini bayi mulai memainkan lidah dan mulutnya untuk menghasilkan bunyi. Tahap ini merupakan tahap awal yang dibutuhkan untuk produksi ujaran selanjutnya. Mendekut diikuti dengan masa permainan vokal. Permainan vokal adalah vokalisasi 
yang menunjukkan berbagai konsonan dan vokal dan beberapa aspek artikulasi dan variatif dalam setiap harinya. Bayi melakukan eksplorasi dan mempraktekkan bagaimana menghasilkan, mengulangi, dan mengubah bunyi. Mengoceh terjadi pada usia 4 sampai 6 bulan. Mengoceh melibatkan produksi bunyi konsonanvokal dalam beragam intonasi dan merupakan bentuk bunyi yang diulang. Kegiatan mengoceh berkebalikan dengan permainan vokal pada kegiatan mendekut, bayi yang mengoceh memproduksi bunyi yang tidak bervariasi namun sering dilakukan. Seperti ba-ba-ba. Bunyi yang dihasilkan bayi mengikuti budaya bahasa dimana bayi tersebut berasal. Usia 8 sampai 10 bulan, ocehan bayi berkembang seperti suatu gema yang disebut ocehan yang berulang-ulang (Sharon Peperkamp, 2003). Ocehan ini terdengar seperti bayi yang bercakap-cakap dengan seseorang. Jenis ini disebut jargon, dan ocehan berirama.

Deteksi bagi bayi yang mengalami kelainan dalam pendengaran dapat dilihat dari bentuk vokalisasi suku kata dan rangkaian suku kata setelah usia 6 bulan. Usia sebelum 6 bulan biasanya vokalisasi bayi akan sama dengan bayi yang bisa mendengar. Setelah usia 6 bulan bayi yang mengalami gangguan pendengaran biasanya vokalisasinya menurun dan pada usia 1 tahun pada waktu itu ocehan vokal terjadi lagi (Ellen V. Et.al, 2012).

Bayi melakukan eksplorasi dan produksi bunyi vokal dibantu oleh penguatan orang dewasa disekitarnya (Beverly Otto, 2015). Ketika orang dewasa meniru bunyi yang diucapkan bayi, lalu berhenti untuk mengambil jeda, dan menunggu bayi merespon merupakan stimulasi yang efektif untuk mengembangkan fonetik pada bayi. Bayi kadang memproduksi satu bunyi yang berbeda dan orang dewasa merespon dengan meniru bunyi yang baru. Pada usia 11 sampai 12 bulan, bayi mulai memproduksi ujaran yang mirip katanya dengan pola bunyi yang secara keseluruhan konsisten. Stimulasi lain yang dapat dilakukan adalah dengan membaca buku bersama dengan bayi. Orang tua dapat melibatkan bayi untuk melihat gambar dengan menggunakan berbagai variasi dalam bunyi dan intonasi. Hasil penelitian menunjukkan bahwa intonasi bunyi ujaran bayi menggambarkan nada, penekanan, dan ritme ujaran ibu ketika membaca buku (Beverly Otto, 2015). Hal ini merupakan awal kemunculan kemampuan membaca dan menulis. Untuk itu, membaca buku bergambar merangsang daya pemahaman pendengaran dan pemahaman fonemik yang berkaitan dengan bahasa lisan dan tulis.

\section{Perkembangan Pengetahuan Fonetik pada Batita}

Pada usia batita, daya pemahaman dan produksi fonem anak semakin jelas. Anak pada usia ini menghindari atau mengolah pengucapan kata yang memiliki bunyi ujaran yang tidak dapat diucapkan. Anak memiliki berbagai cara untuk membunyikan ujaran yang bunyinya sulit untuk diucapkan. Salah satu caranya adalah dengan mengganti atau menghilangkan serta menduplikasi huruf yang sulit diucapkan dengan huruf lain yang bunyinya mirip (Samsunuwiyati Mar'at, 2011).Misalnya, anak yang ingin mengatakan "buka" diucapkan dengan "bupak" dan kata "kakak" dengan "tatak".Batita juga cenderung menolak untuk mengucapkan kata-kata yang diminta oleh orang dewasa untuk ditirukan jika kata tersebut sulit untuk diucapkan. Peran orang tua sangat penting dalam menirukan bunyi ujaran yang diucapkan batita. Misalnya anak mengucapkan "boa" untuk kata "bola". Stimulasi yang dapat dilakukan oleh orang tua yaitu orang tua dapat menirukan kembali kata tersebut dengan lengkap dan jelas.

Pada usia batita, kesadaran dan pemahaman fonemik mulai berkembang dalam mengasosiasikan bunyi dan pola bunyi dalam tulisan di lingkungan anak. Misalnya, Carlo berusia 20 bulan, 
menunjuk berbagai huruf yang ada didalam buku Thomas kesukaannya. Ia menyebutkan bunyi ujaran yang diingatnya. Kemudian, ibunya menyebutkan fonem yang ditunjuk oleh Carlo. Carlo kemudian mulai menunjuk bentuk, dan huruf yang lain. Kegiatan ini merupakan kegiatan yang menunjukkan bahwa batita sudah mulai tertarik untuk mengekplorasi bunyi-bunyi yang berbeda dalam bentuk tulisan di sekitar anak.

\section{Perkembangan Pengetahuan Fonetik pada Usia Prasekolah}

Pada usia prasekolah, kesadaran reseptif anak dan produksi bunyi yang berhubungan dengan bahasa (fonem) hampir berkembang baik. Urutan perkembangan fonem pada manusia menunjukkan kompleksitas yang ada dalam produksi setiap fonem. Misalnya fonem vokal diperoleh lebih awal dari konsonan karena bunyi vokal tidak membutuhkan koordinasi mulut yang rumit. Berbeda dengan bunyi konsonan. Perkembangan fonemik untuk bunyi konsonan menunjukkan cara bunyi tersebut dihasilkan terbagi atas perolehan berdasarkan jenis produksi, dan berdasarkan lokasi dimana bunyi dihasilkan (Beverly Otto, 2015; Saif Al Hadi, 2011). Urutan perolehan bunyi berdasarkan jenis produksinya yaitu a) bunyi nasal, b) bunyi plosif, c) bunyi frikatif, dan d) bunyi afrikatif, Beverly Otto (2015) menjelaskan masing-masing bunyi tersebut beserta dengan contohnya, berikut penjelasannya. Bunyi nasal adalah kondisi mengucapkan bunyi dengan menutup arus udara keluar melalui rongga mulut, misalnya fonem $/ \mathrm{m} /$ dan $/ \mathrm{n} /$. Bunyi plosive adalah kondisi mengucapkan bunyi karena arus udara yang keluar tertutup secara sempurna dan terbuka secara tibatiba, misalnya fonem $/ \mathrm{p} /$ dan $/ \mathrm{b} /$. Bunyi frikatif atau bunyi geser adalah bunyi yang dihasilkan dari udara yang mengalami gesekan dan penyempitan alat ucap, misalnya fonem (f) dan (s). Bunyi afrikatif adalah bunyi kombinasi dari bunyi plosif dan frikatif, misalnya, fonem (c) dan (j). Urutan perolehan berdasarkan lokasi dimana bunyi dihasilkan yaitu a) bunyi glottals, b) bunyi velar, c) bunyi alveolar, d) bunyi dental, dan e) bunyi palatal. Bunyi glottals adalah bunyi yang dihasilkan terbatas pada pangkal tenggorokan atau bunyi yang dihasilkan oleh pita suara dalam rongga antara kedua pita yang disebut glotis, misalnya, (').Bunyi bilabials adalah bunyi yang dihasilkan dari bibir misalnya /f/ dan /v/. Bunyi velar adalah bunyi yang dihasilkan dari langit-langit lunak, yaitu /k/ dan /g/. Bunyi alveolar adalah bunyi yang dihasilkan dari lidah kebatas gusi atas / $t$ /, /d/, dan /s/. Bunyi dental adalah bunyi yang dihasilkan dari gigi; lidah menyentuh gigi atas, misalnya kata "tidak". Bunyi palatal yaitu bunyi yang dihasilkan dari langit-langit keras, misalnya kata "nanas".

Pada usia prasekolah, kesadaran anak terhadap fonem semakin bertumbuh. Kesadaran ini disebut kesadaran fonemik, yaitu kesadaran metalinguistik bahwa kata-kata dibentuk dari berbagai bunyi terpisah yang bisa digunakan (Anne M Bocher, 2012). Anak usia prasekolah mulai fokus dalam menggunakan fonem tertentu ketika berbicara dan sadar bahwa anak dapat memproduksi kata-kata yang memiliki bunyi yang mirip. Permainan bunyi untuk anak prasekolah merupakan kegiatan stimulasi yang mengembangkan fonemik, misalnya, kesamaan bunyi pada kata dalam lagu. Selain itu, membacakan cerita dan puisi yang memiliki rima yang sama mendukung perkembangan fonemik pada anak. Pengetahuan metalinguistik pada fonem juga berkembang ketika anak mulai fokus pada bahasa tulis di lingkungannya. Anak usia prasekolah berinteraksi lebih sering dengan bahasa tulis secara formal ketika orang dewasa membacakan cerita dan secara tidak formal misalnya dilingkungan seperti tanda lalu lintas dan restoran, mulai menghubungkan huruf awal dengan bunyi yang spesifik. Anak usia prasekolah mulai pula mencoba mencocokkan bunyi ujaran 
dengan tulisan dan mengeksplor berbagai ide-ide melalui kertas.

\section{Perkembangan Pengetahuan Fonetik Anak Taman Kanak-kanak}

Anak usia taman kanak-kanak semakin mampu untuk memahami kemiripan dan perbedaan bunyi dalam bentuk permainan. Anak dapat dengan fokus pada rima dan ritme lisan ketika sedang bermain bersama teman. Permainan yang dapat meningkatkan kesadaran bunyi mengenai pola bunyi dan perbedaan bunyi yaitu nyanyian, rima, pembacaan puisi, dan permainan kata. Perolehan pengetahuan fonetik terlihat ketika anak dapat membedakan kemiripan pada bunyi awal dan akhir (Beverly Otto, 2015). Pemahaman anak dalam kemiripan bunyi awal (aliterasi) dan rima mencirikan bahwa anak sudah dapat membedakan fonem, dan mampu melihat kemiripan pada pola-pola ujaran.

Perolehan pengetahuan fonetik anak terhadap bahasa tulis terjadi pula pada masa taman kanak-kanak. Kemunculan kemampuan membaca dan menulis pada usia taman kanak-kanak terkait dengan perolehan pengetahuan reseptif dan ekspresif pada sesuatu yang anak-anak lakukan ketika berusaha membaca dan menulis dan apa yang dikatakan anak mengenai apa yang sedang dilakukan. Bukti pengetahuan fonetik anak pada upaya membaca terlihat ketika anak berusaha untuk membaca dan fokus pada hubungan huruf-bunyi (Beverly Otto, 2015). Ketika anak diminta untuk membaca sebuah buku yang ceritanya cukup dikenal anak, beberapa anak sangat berusaha "seolah-olah mengejanya" fokus pada buku dihadapannya. Ketika anak mengalami kesulitan, beberapa anak kemudian menolak untuk membaca. Ini mengindikasikan bahwa meskipun anak mengetahui bahwa buku tersebut merupakan sumber cerita tapi anak tidak bisa mengejanya. Biasanya dalam bentuk pernyataan "aku tidak tahu bagaimana membaca kata itu", atau "aku tidak tahu kata ini”. Penolakan seperti ini mengindikasikan pemahaman mengenai pentingnya mengeja pada membaca yang sebenarnya. Bahkan ada anak yang setelah berhasil mengeja buku cerita seringkali menoleh kearah orang tua untuk mengkonfirmasi ejaannya betul atau tidak.

Beverly Otto (2015) mengatakan bukti pengetahuan fonetik pada upaya menulis anak memperlihatkan beragam perilaku kemunculan kemampuan menulis yang mengindikasikan bahwa anak mulai fokus pada bagaimana tulisan merepresentasikan bunyi ujaran tertentu. Usaha awal pengejaan pada anak membuktikan perolehan pengetahuan fonetik anak mengenai bahasa tulis. Upaya awal anak dalam pengejaan diklasifikasikan dalam beberapa kategori yaitu pengejaan prafonemik, pengejaan fonemik, dan pengejaan konvensional (Beverly Otto, 2015). Masing-masing kategori menunjukkan pemahaman yang berbeda mengenai bagaimana bunyi ujaran diterjemahkan dalam tulisan.

Pengejaan prafonemik dicirikan dengan pemahaman huruf-huruf dalam tulisan yang terlihat tidak memiliki hubungan dengan bunyi-bunyi spesifik yang biasanya berhubungan dengan hurufnya. Hubungan bunyi dan tulisan direpresentasikan tidak konsisten. Anak berusaha memilih huruf secara acak tanpa mempertimbangkan bunyi-bunyi spesifik yang secara khusus direpresentasikan oleh huruf-huruf. Anak-anak menyambungkan sederet huruf bersama atau sekelompok huruf yang terdiri dari tiga atau empat huruf menjadi unit-unit yang mirip sebuah kata. Contoh, Casey (4 tahun) mencoba untuk membaca tulisan yang ada dalam gambarnya dengan cerita "Casey naik bus sama mas Lintar. Busnya ada tempat tidurnya". Tulisan tersebut terlihat pada gambar berikut ini. 


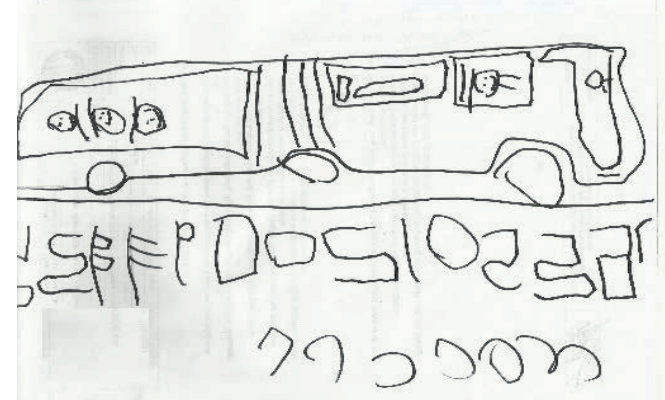

Gambar 1.

Contoh Tulisan Pengejaan Prafonemik Sumber: dokumen pribadi

Pengejaan fonemik dicirikan dengan anak-anak berusaha untuk mengeja fonem-fonem yang tertulis. Tiga kategori pengejaan fonemik yaitu pengejaan fonemik awal, pengejaan nama-huruf, dan pengejaan transisional. Pengejaan fonemik awal mengarah pada contoh-contoh dimana hanya satu atau dua bunyi per kata yang direpresentasikan. Contoh, Casey ( 5 tahun) yang berusaha untuk menulis "Aku Sayang Bunda Martha", ia lakukan dengan menulis "ASE MB AR7”.

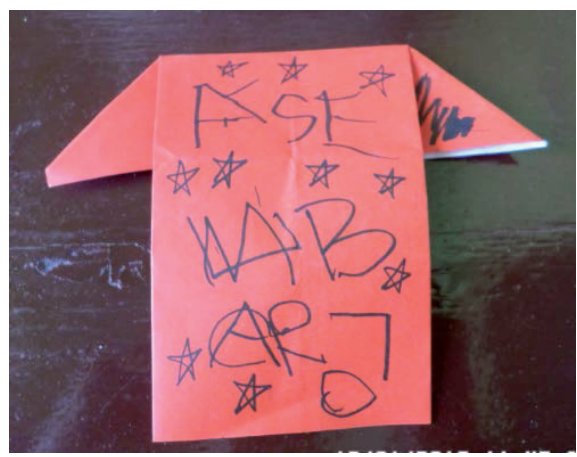

Gambar 2.

Contoh Pengejaan Fonemik Awal Sumber: dokumen pribadi

Pengejaan nama-huruf yaitu setiap nama huruf digunakan untuk merepresentasikan sebuah bunyi; tanpa tambahan huruf yang dimasukkan. Misalnya, menulis pesawat dengan huruf "pswt". Pengejaan transisional dicirikan dengan kata-kata yang memiliki fitur-fitur yang lazim dan pola konsonan/vokal meskipun tidak dibaca secara lazim. Misalnya, tulisan "mat" untuk kata mata.
Pengejaan konvensional/pengejaan yang lazim dicirikan pada mulai berkembangnya sejumlah kecil kosakata tulis untuk kata-kata yang lazim diucapkan. Secara umum, kata-kata ini merupakan kata-kata yang sering digunakan, misalnya nama diri, nama anggota keluarga, nama hewan. Bahkan ketika anak telah memperoleh pengejaan yang lazim untuk beberapa nama-nama, anak masih menggunakan ejaan yang mereka temukan sendiri untuk menulis. Pengejaan dengan huruf rangkap seperti $/ \mathrm{ng} /$, yaitu menggunakan dua huruf untuk menunjukkan satu bunyi. Mengeja dua huruf konsonan menjadi tantangan khusus bagi anak-anak. Anak mencari huruf yang menurutnya merepresentasikan bunyi yang dibutuhkan dalam menulis kata-kata yang memiliki huruf rangkap.

Konsep kata yang dieja menurut Temple et al (dalam Beverly Otto, 2015) pada anak-anak terjadi sangat kompleks terutama untuk penulis pemula. Untuk itu, agar anak dapat mengeja kata, kata tersebut harus memiliki realitas bagi anak sebagai suatu kesatuan. Anak harus mampu membuat kata tersebut tertanam dalam pikirannya. Ada beberapa langkah yang harus dilakukan anak untuk dapat mengeja sebuah kata, yaitu: 1) ucapkan kata tersebut dalam hati, 2) ambil fonem pertama dari fonem lain dalam kata tersebut, 3) pilih daftar huruf-huruf dan temukan satu yang cocok dan tepat dengan fonem tersebut, 4) tuliskan huruf yang sudah ditentukan oleh anak, 5) ulang kembali kata tersebut dalam hati, 6) ingat kembali fonem yang baru saja dieja, pisahkan dari kata, dan lekatkan pada fonem selanjutnya yang akan dieja.

\section{KESIMPULAN}

Perkembangan

pengetahuan fonetik pada rentang anak usia dini memiliki ciri khas yang berbeda disetiap tahapannya. Kemampuan anak membedakan bunyi ujaran, sampai pada pengetahuan bunyi-simbol mengarahkan anak pada potensi keterampilan literasi. 
Telaah tentang perkembangan pengetahuan fonetik anak berguna untuk membantu pendidik dalam mengembangkan kemampuan bahasa anak dalam bentuk stimulasi-stimulasi bahasa yang meliputi kegiatan menyimak, berbicara, membaca, dan menulis. Teori perkembangan bahasa berdasarkan tahapan perkembangan pengetahuan fonetik pada anak perlu dipahami oleh pendidik untuk membantu mengembangkan rangsangan yang sesuai untuk anak dengan usia yang tepat.

\section{DAFTAR PUSTAKA}

Achmad H.P dan Alek Abdullah. 2012. Linguistik Umum. Jakarta: Penerbit Erlangga

Anne M. Bocher. 2012. An Alternative Approach to The Measurement of Phoneme Discrimination and Segmentation in Young Children. Australian Journal of Language and Litearcy. 35(3); 253-270.

Beverly Otto, 2015. Language Development in Early Childhood, Third Edition. USA: Pearson Education, Inc.

Ellen V. Et, al. 2012. Development of Phonological Processing Skills in Children with Specific Language Impairement With and Without Literacy Delay: A 3-Years Longitudinal Study. Journal of Speech, Language, and Hearing Research. 55(?): 1053-1067.

Erika Hoff. 2009. Language Development Fourth Edition. USA: Wadsworth, Cengage Learning.

Muliani Rahmah. 2011. Tata Bunyi. Diakses dari http://mulianirahmahpbsi.blogspot. co.id/2011/12/tatabunyi.html. Pada tanggal 27 November 2016.

Saif Al Hadi. 2011. Klasifikasi Bunyi dan Cara Menghasilkannya. Diakses dari KLASIFIKASI BUNYI DAN CARA MENGHASILKANNYA Belajar Bahasa dan Sastrahttp://berbahasabersastra.blogspot.com $/ 2011 / 01 / \mathrm{kla}$ sifikasi-bunyi-dancara.html\#ixzz4NXu44qQG. Pada Tanggal 19 Oktober 2016

Samsunuwiyati Mar'at. 2011. Psikolinguistik Suatu Pengantar. Bandung: PT Rafika Aditama.

Sharon Peperkamp. 2003. Phonological Acquisition: Recent Attainment and New Challenges. Language and Speech. 46(2-3); 87-113

Sugianto. 2011. Fonem Bahasa Indonesia. Diakses dari https://sites.google.com/site/tatabah asaindonesia/fonem-bahasaindonesia. Pada tanggal 27 November 2016

Ulfa. 2011. Bunyi-bunyi Pertama Bahasa Anak (First Sounds in Children). Diakses dari http://batariguru.blogspot.co.id/201 1/09/bunyi-bunyi-pertama-bahasaanak-first.html. Pada tanggal 19 Oktober 2016 